\title{
Biomarkers and its application in the quality of life assessment of two quilombolas
}

\section{communities}

\author{
Biomarcadores e sua aplicação na avaliação da qualidade de vida de duas comunidades \\ quilombolas
}

Biomarcadores y su aplicación en la evaluación de la calidad de vida de dos comunidades quilombolas

Wanderleia Eleuterio Martins ORCID: https://orcid.org/0000-0003-1132-3270 Federal University of Goiás, Brazil

E-mail: wanderleiaemartins@gmail.com

Mônica de Oliveira Santos

ORCID: https://orcid.org/0000-0001-7110-5430

Federal University of Goiás, Brazil

E-mail: mosbio21@gmail.com

Núbia Aguiar Marinho

ORCID: https://orcid.org/0000-0002-6093-2286

Federal University of Goiás, Brazil

E-mail: nubiamarinho.enf@gmail.com

Aroldo Vieira de Moraes Filho

ORCID: https://orcid.org/0000-0003-2325-1374

Alfredo Nasser University Center, Brazil

E-mail: aroldodemoraes@gmail.com

Aline Rodrigues Gama

ORCID: https://orcid.org/0000-0003-2167-3872

Alfredo Nasser University Center, Brazil

E-mail: alinerodriguesgama15@gmail.com

Arlindo Rodrigues Galvão Filho

ORCID: https://orcid.org/0000-0003-2151-8039

Federal University of Goiás, Brazil

E-mail: argfilho@gmail.com

Raylane Pereira Gomes

ORCID: https://orcid.org/0000-0001-8495-1361

Federal University of Goiás, Brazil

E-mail: raylanepgomes@gmail.com

Débora de Jesus Pires

ORCID: https://orcid.org/0000-0002-6144-2633

State University of Goiás, Brazil

E-mail: dejbo@hotmail.com

Lilian Carla Carneiro

ORCID: https://orcid.org/0000-0003-4067-1506 Federal University of Goiás, Brazil

E-mail: carlacarneirolilian@gmail.com

\begin{abstract}
Laboratory analysis has an impact on the different stages of health: prevention, diagnosis, prognosis and therapeutic. Blood samples were collected from quilombolas representatives of the two communities. The samples were stored with anticoagulants (EDTA and fluoride) and without anticoagulant. Were performers the laboratory tests (blood count, lipidogram, urea, creatinine, glycemia and vitamin D). The results showed that $22 \%$ of the quilombolas presented values of glycemia among 100 and $126 \mathrm{mg} \backslash \mathrm{dL}$. Results of the lipidogram test showed $24.4 \%$ presented triglyceride variation above $150 \mathrm{mg} / \mathrm{dL} ; 57.7 \%$ presented cholesterol above $190 \mathrm{mg} / \mathrm{dL} ; 35.5 \%$ had HDL levels below $40 \mathrm{mg} / \mathrm{dL}$ and $66.6 \%$ had LDL levels above $110 \mathrm{mg} / \mathrm{dL}$. Regarding the hemogram, $15.5 \%$ of the hematocrit tests and $24.4 \%$ of the hemoglobin tests were found, with values lower than the reference values. Vitamin D presented $40 \%$ of patients with values below $30 \mathrm{ng} / \mathrm{mL}$. Glomerular filtration rate calculations showed that $66.66 \%$ presented among mild to severe changes in renal filtration rate. The data obtained, show that was possible to highlight that among the quilombolas, there are metabolic disorders of carbohydrates, lipids and vitamin $\mathrm{D}$, which correlate with changes in BMI, justifying cases of overweight.
\end{abstract}

Keywords: Neglected population; Hemogram; Lipidogram; Vitamin D; Quality of life; Blood. 


\section{Resumo}

A análise laboratorial tem impacto nas diferentes etapas da saúde: prevenção, diagnóstico, prognóstico e terapêutica. Amostras de sangue foram coletadas de representantes quilombolas de duas comunidades. As amostras foram armazenadas com anticoagulantes (EDTA e flúor) e sem anticoagulante. Foram realizados os exames laboratoriais (hemograma, lipidograma, uréia, creatinina, glicemia e vitamina D). Os resultados mostraram que $22 \%$ dos quilombolas apresentaram valores de glicemia entre 100 e $126 \mathrm{mg} \backslash \mathrm{dL}$. Os resultados do teste de lipidograma mostraram que 24,4\% apresentavam variação de triglicerídeos acima de $150 \mathrm{mg} / \mathrm{dL} ; 57,7 \%$ apresentavam colesterol acima de $190 \mathrm{mg} / \mathrm{dL} ; 35,5 \%$ tinham níveis de HDL abaixo de $40 \mathrm{mg} / \mathrm{dL}$ e 66,6\% tinham níveis de LDL acima de $110 \mathrm{mg} / \mathrm{dL}$. Em relação ao hemograma, foram encontrados 15,5\% dos testes de hematócrito e 24,4\% dos testes de hemoglobina, com valores inferiores aos valores de referência. A vitamina D apresentou $40 \%$ dos pacientes com valores abaixo de $30 \mathrm{ng} / \mathrm{mL}$. Os cálculos da taxa de filtração glomerular mostraram que 66,66\% apresentaram alterações leves a graves na taxa de filtração renal. Os dados obtidos mostram que foi possível destacar que, entre os quilombolas, existem distúrbios metabólicos de carboidratos, lipídios e vitamina $\mathrm{D}$, que se correlacionam com alterações no IMC, justificando os casos de excesso de peso.
\end{abstract}

Palavras-chave: População negligenciada; Hemograma; Lipidograma; Vitamina D; Qualidade de vida; Sangue.

\title{
Resumen
}

El análisis de laboratorio incide en las diferentes etapas de la salud: prevención, diagnóstico, pronóstico y terapéutico. Se recolectaron muestras de sangre de quilombolas representantes de las dos comunidades. Las muestras se almacenaron con anticoagulantes (EDTA y fluoruro) y sin anticoagulante. Se realizaron las pruebas de laboratorio (hemograma, lipidograma, urea, creatinina, glucemia y vitamina D). Los resultados mostraron que el $22 \%$ de los quilombolas presentaron valores de glucemia entre 100 y $126 \mathrm{mg} \backslash \mathrm{dL}$. Los resultados de la prueba de lipidograma mostraron que el 24,4\% presentó variación de triglicéridos por encima de $150 \mathrm{mg} / \mathrm{dL}$; El 57,7\% presentó colesterol por encima de $190 \mathrm{mg} / \mathrm{dL}$; El 35,5\% tenía niveles de HDL por debajo de $40 \mathrm{mg} / \mathrm{dL}$ y el 66,6\% tenían niveles de LDL por encima de $110 \mathrm{mg} / \mathrm{dL}$. En cuanto al hemograma, se encontraron 15,5\% de las pruebas de hematocrito y $24,4 \%$ de las de hemoglobina, con valores inferiores a los valores de referencia. La vitamina D presentó al $40 \%$ de los pacientes valores inferiores a $30 \mathrm{ng} / \mathrm{mL}$. Los cálculos de la tasa de filtración glomerular mostraron que el 66,66\% se presentó entre cambios leves a graves en la tasa de filtración renal. Los datos obtenidos, muestran que se pudo destacar que entre los quilombolas, existen desórdenes metabólicos de carbohidratos, lípidos y vitamina $\mathrm{D}$, que se correlacionan con cambios en el IMC, justificando casos de sobrepeso.

Palabras clave: Población desatendida; Hemograma; Lipidograma; Vitamina D; Calidad de vida; Sangre.

\section{Introduction}

According to Seidel and Zannon (Seidl, et al., 2004), quality of life refers to the perception of the general population. In the health area, the interest about quality of life concept has influenced public policies and practices. Therefore, the conditioners of the health/ disease process are multifactorial if related to social, historical, economic, psychological, life experiences and world view of each individual and the community where he is inserted. The quality of life in a community depends on its characteristics, especially in quilombola communities, which have unique characteristics. In the state of Goiás there are 33 quilombola communities certified and 27 in process of certification by the Palmares Foundation (Campos et al., 2008; SEDSG, 2018).

The term "quilombo" derives from Kimbundu, an African language belonging to the Bantu linguistic family. In Brazil the word was resemantized and "quilombo" became any group of black people found together, with autonomy of subsistence that did not prove that they were freeded (Arruti, 2006). In 1850, the law of lands written and worked in Brazil, reclassified the term quilombola, classifying the Africans and their descendants in the category of "freedmen", excluding them from being Brazilian (Leite, 1999).

In 2003 came Decree n. 4887/2003, of the National Institute for Colonization and Agrarian Reform (INCRA), regulating the identification, recognition, demarcation and titling of the lands occupied by remnants of the quilombola communities, through the technical identification, delimitation report and through the anthropological report, produced by a group of anthropologists from the Palmares Cultural Foundation (Arruti, 2006).

It is important to apply the indicators to evaluate the effectiveness, efficiency and impact of treatments in patients with injuries and in the comparison of different processes used to control health problems. The daily healthcare practices of the 
health services bring information about the psychosocial development of the diseases, the improvement of the incapacities about the affected individuals, providing better knowledge and adaptation of the patient to this new condition of life, influencing for the necessary improvements in the different processes related to the quality of life of the population (ANS, 2011).

Based on avaliation about quality of life, the objective of this study was to perform a complete blood count, vitamin D, lipidogram, blood glucose, urea, creatine, and socio-demographic data and life habits of members of the Cascade communities in Aparecida de Goiânia-GO and in the community of Almeidas in Silvânia-GO.

\section{Methodology}

\subsection{Approval on the Ethics Committee}

The research was carried out after approval by the Research Ethics Committee of the Federal University of Goiás CEP / UFG (opinion no. 65338017.6.0000.5083) on 04/07/2017. All procedures were performed according to the guidelines of the Resolutions of the National Health Council under regulations 466/2012 and 510/2016 (Gusman, et al., 2016). The research is of the qualitative and quantitative type, according with (Koche, 2011).

\subsection{Characterization of the quilombola communities studied}

At Aparecida de Goiânia-GO, the quilombola community of Cascata and Dellfiore village settled down. The arrival and fixation of the Francisco family brought the identity dimensions as quilombola, and possibility of the official recognition of that community by the Palmares Cultural Foundation (FCP) (Santos \& Silva, 2014).

On the other hand, the Almeidas community is located in the rural area of the municipality of Silvânia, southeast region of Goiás. Among the family residences, 12 units are close to the so-called "little church" region, and the rest are dispersed throughout the rural area, some of which are very distant from each other (Santos \& Silva, 2014).

The two participating quilombola communities are located in Jardim Cascata, in the municipality of Aparecida de Goiânia-GO, and in the rural area of the municipality of Silvânia-GO.

\subsection{Study Design}

A quantitative and qualitative cross-sectional study was carried out in two quilombola communities. The datas collection instruments were applied, including the quilombolas older than eighteen years and who signed the free and informed consent term. The data collection instrument consisted of thirteen subjective questions and six objective questions.

Blood samples were collected for hemogram, lipidogram, fasting glucose, urea, and creatinine laboratory tests performed at the laboratory Margarida / UFG and vitamin D, performed at the Laboratory of Clinical Analyzes of Clinicas Hospital from Federal University of Goiás/UFG.

\subsection{Laboratory clinical analyzes performed for blood samples from quilombolas}

\subsubsection{Glucose Dosing Technique}

The glycemia was determined in fluoridated plasma by the enzymatic method with the action of the enzyme Glucose Oxidase and Peroxidase. The results were interpreted with reference values for normality between 60 and $99 \mathrm{mg} / \mathrm{dL}$; altered between 100 to $125 \mathrm{mg} / \mathrm{dL}$ and diabetes mellitus equal or greater than $126 \mathrm{mg} / \mathrm{dL}$. The reading was performed in the Bioplus 200 apparatus by spectrophotometry using the Glucose Biosystems ${ }^{\circledR}$ kit, according to the manufacturer's guidelines (SBD, 2002). 


\subsubsection{Lipid Dosing Technique}

The methodology used in the serum was that described by Jaffe (Xavier, et al., 2013; Dusse, et al., 2017). The serum sample was obtained by venous puncture without anticoagulant; fasting is recommended for at least eight hours. The reading was performed in the Bioplus 200 device by spectrophotometry using the Creatinine Biosystems ${ }^{\circledR}$ kit, the reference values adopted for creatinine were 0.5 to $1.2 \mathrm{mg} / \mathrm{dL}$.

With creatinine dosing results, adding data such as weight, age, and gender of the patient, the creatinine clearance was calculated which provided an estimate of the GFR (glomerular filtration rate) as described below:

Estimating the glomerular filtration rate (GFT) in adults older than 16 years. Cockcroft-Gault formula.

$(\mathrm{GFT})=(140$-age $) \mathrm{X}$ (weight) $\mathrm{X} \mathrm{K} / 72 \mathrm{X} \mathrm{Cr}$

The age was expressed in years, the body weight was expressed in kilograms and serum creatinine $(\mathrm{Cr})$ was expressed in $\mathrm{mg} / \mathrm{dL}$. The constant $\mathrm{K}$ has a value of 1.00 for men and 0.85 for women. Urea enzyme was dosed in serum with reference values between 15 and $45 \mathrm{mg} / \mathrm{dL}$, using the enzymatic colorimetric method. The reading was performed on the Bioplus 200 apparatus by spectrophotometry using the Urea Biosystems® kit (Sodre, et al., 2007).

\subsubsection{Dosing technique of total 25-hydroxyvitamin D}

The methodology used to dose vitamin D, was chemiluminescence, the test measured two forms at $25(\mathrm{OH}) \mathrm{D} 2$ (vitamin D2) and the form cholecalciferol-25 (OH) D3 (vitamin D3). The total of $2 \mathrm{~mL}$ sample of the serum participants were collected, stored on ice and transported to the Clinical Laboratory of the University Hospital - HC, from Federal University of Goiás, in the city of Goiânia, state of Goiás. The blood samples were analyzed by the Microparticle Chemiluminescent Immunoassay (CMIA) method in the VIDAS ${ }^{\circledR}$ equipment, using the bioMérieux ${ }^{\circledR}$ Kit, with reference values: Healthy> $20 \mathrm{ng}$ / mL; Risk groups 30-60 ng / mL; Toxicity and Hyperkalemia> $100 \mathrm{ng} / \mathrm{mL}$. The laboratory report provided the results of the total HIDROXI-vitamin D levels.

\subsubsection{Complete blood count technique}

The blood samples collected from the volunteers were stored in specific bottles with anticoagulant EDTA (ethylene diamine tetra acetic acid) and transported to the laboratory, where it was processed in automatic analyzers using the methodology of Electrical Impedance Focused. For this, the Hematology-Diagon apparatus - ABX Micros 60 / Advia 60® and the reagents Diacleaner (20215 Ax) 1 L (Silva and D'Amico, 2010).

Cell counters determined the number of erythrocytes, leukocytes / mm3, hemoglobin concentration, the actual value of $\mathrm{MCV}$ (mean corpuscular volume), HCM (mean corpuscular hemoglobin), CHCM (mean corpuscular hemoglobin concentration), calculation of the erythrocyte anisocytes (RDW), of the platelets (PDW) and provided cell volume distribution histograms (Faludi, et al., 2017). The blood sample used to perform the hemogram was obtained to avoid variations in sample collection, the procedure was performed with the patient rested, well accommodated (lying down or sitting). The relationship between the blood volume collected and the anticoagulant concentration was added to avoid hemodilution or hemoconcentration (Failace, 2015).

Was used the anticoagulant EDTA with potassium salt (EDTA-K2), in the final concentration of 1.5 to $2.2 \mathrm{mg} / \mathrm{mL}$ of blood. The results were correlated with age, sex and medication use (Mattos, et al., 2012).

\subsection{Statistical analyzes}

For the data analysis was used the SPSS 21.0 statistical program. Variables with normal distribution were expressed as mean \pm standard deviation, while variables with non-normal distribution were expressed in median and interquartile range. 
Were used the Student's t-test for analyze independent samples and the Mann-Whitney test to analyze non-parametric date.

\section{Results}

The data of 26 habitants in Silvânia-GO and 19 habitants in Aparecida de Goiânia-GO, were analyzed. Nearly 11 quilombolas reported headache and frequent pain in the body, four do not sleep well, 13 present fatigue, weakness and anxiety, 12 are sedentary, 18 have frequent use of alcoholic beverages and 10 are smokers (data not shown). Regarding self-perception and self-diagnosis, the participants reported the presence of diseases such as diabetes, hypertension, hypercholesterolemia and depression.

When observed the lipid variables for both communities, statistical significance was found for total cholesterol and LDL cholesterol with $\mathrm{p}<0.05$. In Table 1 we report the results of blood glucose and lipid variables of the quilombolas from both communities.

Table 1. Variables of lipid and glycemia for the two communities studied.

\begin{tabular}{|c|c|c|c|c|}
\hline & Reference values** & $\begin{array}{c}\text { Almeida Community } \\
\qquad(\mathrm{n}=26)\end{array}$ & $\begin{array}{c}\text { Cascata Community } \\
(n=19)\end{array}$ & p value \\
\hline Cholesterol (mg/ dL) & $<190 \mathrm{mg} / \mathrm{dL}$ & $217 \pm 54$ & $179 \pm 48$ & 0.01* \\
\hline \multirow{2}{*}{ Triglycerides (mg/ dL) } & Fasting $<150 \mathrm{mg} / \mathrm{dL}$ & $120(98-142)$ & $127(68-163)$ & 0.91 \\
\hline & without Fasting $<175 \mathrm{mg} / \mathrm{dL}$ & & & \\
\hline HDL (mg/ dL) & $>40 \mathrm{mg} / \mathrm{dL}$ & $47(36-55)$ & $48(36-62)$ & 0.6 \\
\hline LDL (mg/ dL) & $<110 \mathrm{mg} / \mathrm{dL}$ & $139 \pm 48$ & $104 \pm 35$ & 0.01* \\
\hline \multirow{4}{*}{ Glycemia (mg/ dL) } & Normality: $60-99 \mathrm{mg} / \mathrm{dL}$ & \multirow{4}{*}{$87(75-98)$} & \multirow{4}{*}{$86(81-105)$} & \multirow{4}{*}{0.52} \\
\hline & Altered: $100-125 \mathrm{mg} / \mathrm{dL}$ & & & \\
\hline & DM: $\geq 126 \mathrm{mg} / \mathrm{dL}$ & & & \\
\hline & Postprandial > $200 \mathrm{mg} / \mathrm{dL}$ & & & \\
\hline
\end{tabular}

Values expressed as mean $\pm \mathrm{SD}$ (standard deviation) or median (interquartile range). Legend: $\mu \mathrm{L}$ : micro liters; g: grams; DM: diabetes mellitus. In bold are the abnormal values; * p-value $\leq 0.05$ (Student's t-test). ** Source: Brazilian Society of Endocrinology (2018).

On Table 2, we present the results obtained from the analysis of Urea, creatinine, Vitamin D tests and calculation of the glomerular filtration rate of the quilombolas of the studied communities. When compared to the reference values, there was one that the creatinine result was higher than the recommended maximum and in the community of Aparecida de Goiânia-GO, according to the reference values; there were four patients with creatinine considered high. 
Table 2. Values of vitamin D, urea, creatine and glomerular filtration rate of the two communities studied.

\begin{tabular}{|c|c|c|c|c|}
\hline Cascata Community & TFG (mL/min) & Urea (mg/dL) & Creatine (mg/dL) & Vitamin D (ng/m) \\
\hline 1 & 105.8 & 20 & 1.3 & 32.2 \\
\hline 2 & $59.10 * *$ & 19 & 1.6 & 24.3 \\
\hline 3 & $64.10 *$ & 18 & 1 & 24.9 \\
\hline 4 & 147.5 & 14 & 0.8 & 26.1 \\
\hline 5 & $79.60 *$ & 23 & 1.1 & 34.6 \\
\hline 6 & 107 & 14 & 0.9 & 31.9 \\
\hline 7 & $63.50 *$ & 43 & 1.8 & 29.1 \\
\hline 8 & $67.40^{*}$ & 19 & 1.3 & 36.6 \\
\hline 9 & 115 & 25 & 0.9 & 32.4 \\
\hline 10 & 96.7 & 23 & 0.6 & 23.4 \\
\hline 11 & $80.10^{*}$ & 21 & 0.9 & 39.4 \\
\hline 12 & 97.6 & 28 & 0.9 & 23.8 \\
\hline 13 & 112.2 & 10 & 0.7 & 30.6 \\
\hline 14 & $73.60 *$ & 18 & 0.9 & 37.6 \\
\hline 15 & $64.20 *$ & 20 & 1.1 & 33.64 \\
\hline 16 & $82.20 *$ & 30 & 0.9 & 48 \\
\hline 17 & $61.50 *$ & 33 & 1.1 & 37.4 \\
\hline 18 & $67.10^{*}$ & 19 & 1.1 & 30.9 \\
\hline 19 & $86.00 *$ & 22 & 0.8 & 39.6 \\
\hline \multicolumn{5}{|l|}{ Almeida Community } \\
\hline 1 & $75.60 *$ & 36 & 0.9 & 31.4 \\
\hline 2 & $76.50 *$ & 33 & 1.1 & 42.4 \\
\hline 3 & 96.4 & 34 & 0.9 & 33.3 \\
\hline 4 & 105.4 & 43 & 1 & 29.1 \\
\hline 5 & $88.00 *$ & 38 & 0.8 & 27.2 \\
\hline 6 & 106.3 & 22 & 0.8 & 41.1 \\
\hline 7 & $59.40 * *$ & 16 & 1.2 & 33.1 \\
\hline 8 & $85.90 *$ & 21 & 0.9 & 30.1 \\
\hline 9 & $87.80 *$ & 32 & 1 & 29 \\
\hline 10 & $41.10 * * *$ & 43 & 1.8 & 28.3 \\
\hline 11 & $76.70 *$ & 32 & 1 & 27.8 \\
\hline 12 & $48.80 * *$ & 31 & 1.1 & 23 \\
\hline 13 & $88.50 *$ & 38 & 1 & 32.8 \\
\hline 14 & $60.20 *$ & 43 & 1.2 & 37.4 \\
\hline 15 & $58.00 * *$ & 26 & 1.1 & 30.4 \\
\hline 16 & 100.4 & 41 & 0.7 & 27.6 \\
\hline 17 & 106.6 & 23 & 0.8 & 32.6 \\
\hline 18 & $65.40 *$ & 34 & 0.9 & 36.5 \\
\hline 19 & $60.30 *$ & 46 & 1 & 33.5 \\
\hline 20 & $81.70^{*}$ & 18 & 0.9 & 26 \\
\hline 21 & $45.10^{* * *}$ & 25 & 1.1 & 27 \\
\hline 22 & 115.7 & 18 & 1 & 31 \\
\hline 23 & 101.2 & 19 & 1 & 29 \\
\hline 24 & $59.90 * *$ & 14 & 0.9 & 32 \\
\hline 25 & 144.2 & 20 & 0.8 & 24.2 \\
\hline 26 & $54.10^{* * *}$ & 28 & 0.9 & 25 \\
\hline
\end{tabular}

Values expressed as mean \pm SD (standard deviation) or median (interquartile range). Legend: mL: milliliters; min: minutes; mg: milligrams; $\mathrm{dL}$ : deciliters; ng: nano grams $\uparrow \mathrm{p}$-value $\leq 0.05$ (Mann-Withney test) Legend of reference values of glomerular filtration rate: Normal:> $90 \mathrm{~mL}$ / min x 1.73m2. *Discrete Reduction: $89-60 \mathrm{ml} / \mathrm{min}$ x 1,73m2); **Discret Reduction - Moderate: 59 - $45 \mathrm{ml} / \mathrm{min} \times 1,73 \mathrm{~m} 2$; ***ModerateSevere Reduction: 44 - $30 \mathrm{~mL} / \mathrm{min}$ x 1,73m2; Severe Reduction: $29-15 \mathrm{~mL} / \mathrm{min}$ x 1,73m2. Renal Failure: $<15 \mathrm{~mL} / \mathrm{min} \times 1.73 \mathrm{~m} 2$; In bold are the abnormal values of vitamin D (below $30 \mathrm{ng} / \mathrm{m}$ ). (Brazilian Society of Nephrology $\backslash$ Brazilian Society of Clinical Pathology (2018).

The hemogram results are shown in Table 3. 
Table 3. Blood count variables for both communities.

\begin{tabular}{|c|c|c|c|c|}
\hline & Reference values** & $\begin{array}{c}\text { Almeida Community } \\
\qquad(\mathrm{n}=26)\end{array}$ & $\begin{array}{c}\text { Cascata Community } \\
(n=19)\end{array}$ & p-value \\
\hline Blood cells $(106 / \mu \mathrm{L})$ & & $4.6(4.4-4.8)$ & $4.6(4.2-4.8)$ & 0.59 \\
\hline Hematocrit (\%) & $\begin{array}{c}\text { Male: } 38 \text { to } 52 \% \\
\text { Female: } 35 \text { to } 47 \%\end{array}$ & $42(39-44)$ & $41(38-45)$ & 0.81 \\
\hline Hemoglobin (g / dL) & $\begin{array}{l}\text { Male: } 13 \text { to } 18 \mathrm{~g} / \mathrm{dL} \\
\text { Female: } 12 \text { to } 16 \mathrm{~g} / \mathrm{dL}\end{array}$ & $13.9 \pm 1.38$ & $13.9 \pm 1.5$ & 0.99 \\
\hline Leukocytes $(\mu \mathrm{L})$ & 4000 to $11000 / \mu \mathrm{L}$ & $6146 \pm 1629$ & $4747 \pm 1410$ & $<0.01 *$ \\
\hline Total Neutrophils $(\mu \mathrm{L})$ & 1800 to $8000 / \mu \mathrm{L}$ & $3487 \pm 1279$ & $2356 \pm 1042$ & $<0.01 *$ \\
\hline Lymphocyte $(\mu \mathrm{L})$ & 900 to $4000 / \mu \mathrm{L}$ & $2094 \pm 548$ & $1976 \pm 529$ & 0.47 \\
\hline Eosinophil $(\mu \mathrm{L})$ & 0 to $500 / \mu \mathrm{L}$ & $127(59-215)$ & $144(55-231)$ & 0.95 \\
\hline Platelets $(\mu \mathrm{L})$ & 140000 to $450000 / \mu \mathrm{L}$ & $220692 \pm 53910$ & $196136 \pm 74429$ & 0.2 \\
\hline
\end{tabular}

Value expressed as mean \pm SD (standard deviation) or median (interquartile range). Legend: $\mu \mathrm{L}$ : microliters; g: grams; $*$ p-value $\leq 0.05$ (Student's t-test). ** Source: Ministry of Health (2018).

The Table 4 shows the Mann Whitney statistical test, to verify whether the Almeida community (rural area) and the Cascades community (urban area) presented statistical variations for the tests of total cholesterol, LDL cholesterol, urea, creatinine, leukocytes (as a function of total neutrophils).

The significance between all parameters studied in the communities of Almeidas (Silvânia-GO) and Cascatas (Aparecida de Goiânia-GO) was tested by performing a Spermanm statistical analysis. The data are shown in Table 5. 
Research, Society and Development, v. 10, n. 7, e2310716186, 2021

(CC BY 4.0) | ISSN 2525-3409 | DOI: http://dx.doi.org/10.33448/rsd-v10i7.16186

Table 4. Mann Whitney statistical test for the parameters studied in the two quilombola communities.

\begin{tabular}{|c|c|c|c|c|c|c|c|c|c|c|}
\hline \multicolumn{11}{|c|}{ Mann-Whitney U Test By variable Colunas1 Marked tests are significant at $p<, 05000$} \\
\hline & Rank Sum & Rank Sum & $\mathbf{U}$ & $\mathbf{Z}$ & p-level & $\mathbf{Z}$ & p-level & Valid N & Valid N & 2*1 sided \\
\hline Sex & 675,0000 & 360,0000 & 210,0000 & $-0,36116$ & 0,717982 & $-0,42997$ & 0,667218 & 30 & 15 & 0,729970 \\
\hline Age & 743,5000 & 291,5000 & 171,5000 & 1,28813 & 0,197702 & 1,28898 & 0,197407 & 30 & 15 & 0,200132 \\
\hline Weight & 742,5000 & 292,5000 & 172,5000 & 1,26405 & 0,206212 & 1,26585 & 0,205569 & 30 & 15 & 0,208781 \\
\hline Height & 642,5000 & 392,5000 & 177,5000 & $-1,14367$ & 0,252763 & $-1,14913$ & 0,250504 & 30 & 15 & 0,255991 \\
\hline Diastolic Pressure & 711,0000 & 324,0000 & 204,0000 & 0,50562 & 0,613123 & 0,51973 & 0,603252 & 30 & 15 & 0,625394 \\
\hline Systolic Pressure & 665,5000 & 369,5000 & 200,5000 & $-0,58989$ & 0,555264 & $-0,62931$ & 0,529149 & 30 & 15 & 0,559412 \\
\hline Cholesterol & 794,5000 & 240,5000 & 120,5000 & 2,51606 & 0,011868 & 2,51640 & 0,011857 & 30 & 15 & 0,010698 \\
\hline Triglycerides & 702,0000 & 333,0000 & 213,0000 & 0,28893 & 0,772638 & 0,28901 & 0,772573 & 30 & 15 & 0,784312 \\
\hline HDL & 648,5000 & 386,5000 & 183,5000 & $-0,99920$ & 0,317697 & $-1,00016$ & 0,317235 & 30 & 15 & 0,321573 \\
\hline LDL & 817,0000 & 218,0000 & 98,0000 & 3,05780 & 0,002230 & 3,05820 & 0,002227 & 30 & 15 & 0,001729 \\
\hline Blood glucose & 690,5000 & 344,5000 & 224,5000 & 0,01204 & 0,990395 & 0,01204 & 0,990390 & 30 & 15 & 0,990508 \\
\hline Creatinine & 729,5000 & 305,5000 & 185,5000 & 0,95105 & 0,341581 & 0,96946 & 0,332318 & 30 & 15 & 0,345622 \\
\hline Urea & 773,0000 & 262,0000 & 142,0000 & 1,99841 & 0,045674 & 2,00170 & 0,045317 & 30 & 15 & 0,046130 \\
\hline Hemaceae & 765,0000 & 270,0000 & 150,0000 & 1,80579 & 0,070952 & 1,80614 & 0,070897 & 30 & 15 & 0,072597 \\
\hline Hematocrit & 720,0000 & 315,0000 & 195,0000 & 0,72232 & 0,470101 & 0,72251 & 0,469984 & 30 & 15 & 0,481892 \\
\hline Hemoglobin & 726,5000 & 308,5000 & 188,5000 & 0,87882 & 0,379501 & 0,87934 & 0,379219 & 30 & 15 & 0,383732 \\
\hline Leukocytes & 794,0000 & 241,0000 & 121,0000 & 2,50403 & 0,012279 & 2,50592 & 0,012214 & 30 & 15 & 0,011517 \\
\hline Total Neutrophils & 818,0000 & 217,0000 & 97,0000 & 3,08188 & 0,002057 & 3,08198 & 0,002056 & 30 & 15 & 0,001576 \\
\hline Lymphocytes & 719,0000 & 316,0000 & 196,0000 & 0,69824 & 0,485029 & 0,69824 & 0,485029 & 30 & 15 & 0,496925 \\
\hline Eosinophils & 637,0000 & 398,0000 & 172,0000 & $-1,27609$ & 0,201925 & $-1,27626$ & 0,201865 & 30 & 15 & 0,208781 \\
\hline Platelets & 748,5000 & 286,5000 & 166,5000 & 1,40851 & 0,158980 & 1,40870 & 0,158925 & 30 & 15 & 0,160699 \\
\hline D Vitamin & 654,0000 & 381,0000 & 189,0000 & $-0,86678$ & 0,386064 & $-0,86686$ & 0,386017 & 30 & 15 & 0,396973 \\
\hline
\end{tabular}

Subtitle: LDL: Low Density Lipoproteins, HDL (High Density Lipoproteins). Source: Research data. 
Table 5. Statistical Evaluation of Spermanm.

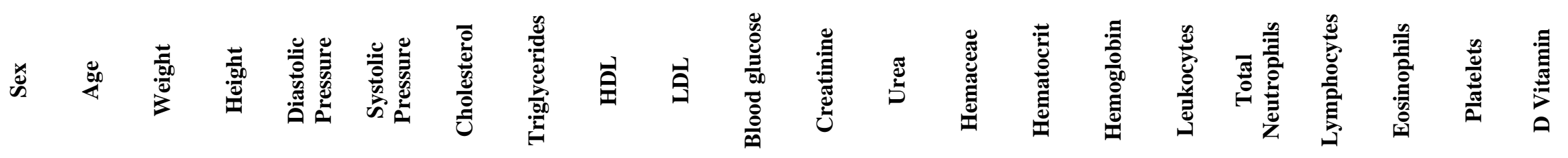

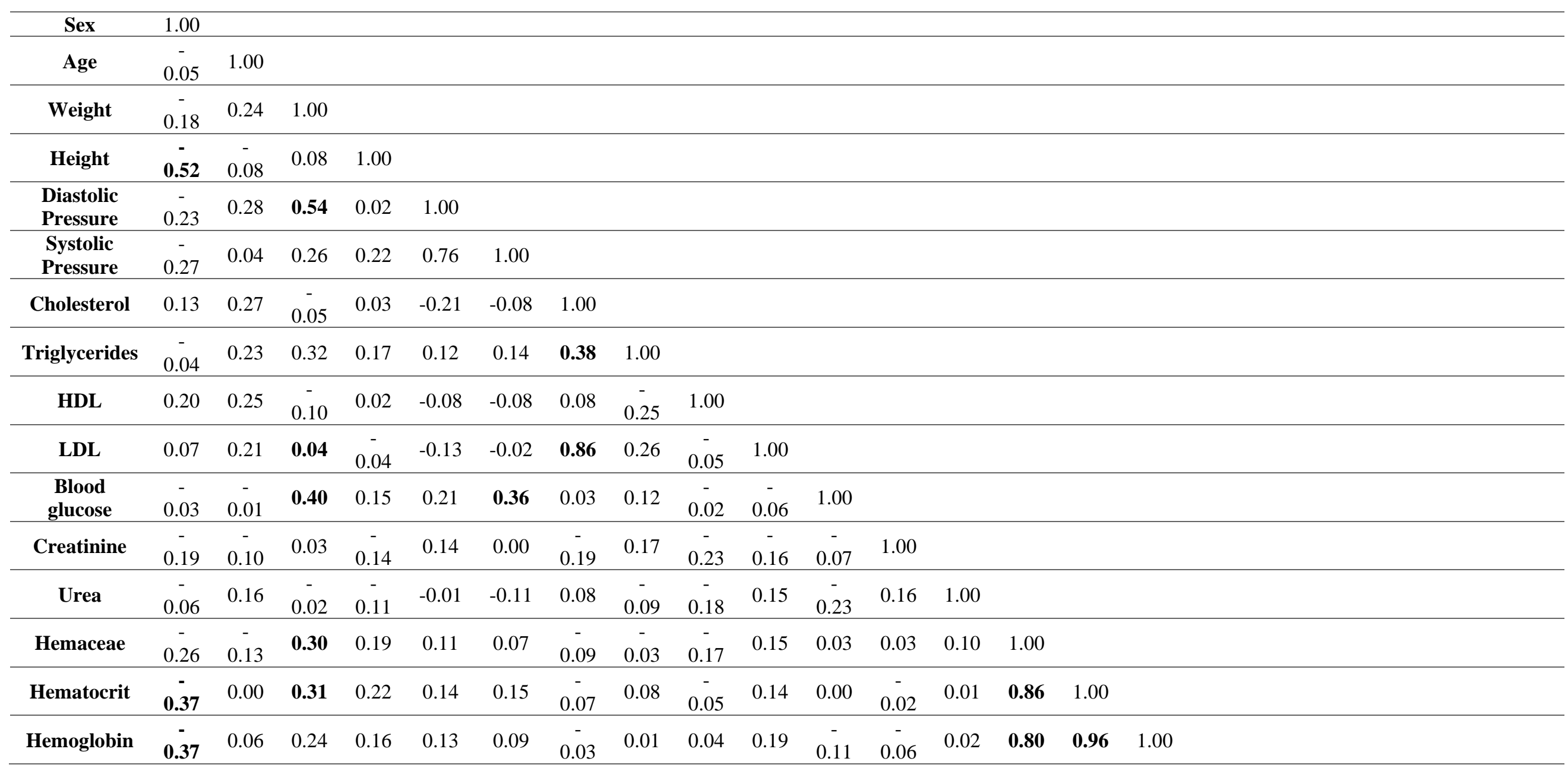


Research, Society and Development, v. 10, n. 7, e2310716186, 2021

(CC BY 4.0) | ISSN 2525-3409 | DOI: http://dx.doi.org/10.33448/rsd-v10i7.16186

\begin{tabular}{|c|c|c|c|c|c|c|c|c|c|c|c|c|c|c|c|c|c|c|c|c|c|c|}
\hline Leukocytes & 0.16 & 0.02 & 0.25 & $\begin{array}{c}- \\
0.03\end{array}$ & 0.01 & -0.06 & 0.41 & 0.13 & $\begin{array}{c}- \\
0.04\end{array}$ & 0.45 & 0.10 & $\begin{array}{c}- \\
0.10\end{array}$ & $\begin{array}{c}- \\
0.02\end{array}$ & 0.17 & 0.11 & 0.13 & 1.00 & & & & & \\
\hline $\begin{array}{c}\text { Total } \\
\text { Neutrophils } \\
\end{array}$ & 0.05 & $\overline{-}-$ & 0.30 & - & 0.05 & -0.08 & 0.25 & 0.02 & - & 0.27 & 0.19 & 0.05 & 0.06 & 0.20 & 0.10 & 0.09 & 0.91 & 1.00 & & & & \\
\hline $\begin{array}{l}\text { Lymphocyte } \\
\text { s }\end{array}$ & 0.33 & 0.04 & $\overline{-}$ & $\begin{array}{c}- \\
0.04\end{array}$ & -0.06 & 0.00 & 0.42 & 0.20 & 0.17 & 0.50 & $0 . \overline{25}$ & $-\overline{15}$ & $\begin{array}{c}- \\
0.12\end{array}$ & 0.07 & 0.04 & 0.09 & 0.56 & 0.23 & 1.00 & & & \\
\hline Eosinophils & 0.15 & 0.05 & 0.00 & $\begin{array}{c}- \\
0.15\end{array}$ & 0.08 & 0.04 & 0.15 & 0.06 & 0.10 & 0.19 & $\begin{array}{c}- \\
0.06\end{array}$ & $\begin{array}{c}- \\
0.26\end{array}$ & $\begin{array}{c}- \\
0.20\end{array}$ & $\begin{array}{c}- \\
0.10\end{array}$ & $\overline{-}$ & 0.02 & 0.35 & 0.15 & 0.40 & 1.00 & & \\
\hline Platelets & 0.09 & $\overline{-}-$ & 0.06 & 0.10 & -0.24 & -0.09 & 0.13 & 0.07 & $\overline{-}-$ & 0.17 & 0.08 & $\begin{array}{c}- \\
0.11\end{array}$ & 0.05 & 0.09 & 0.18 & $\overline{-}-$ & 0.48 & 0.40 & 0.40 & 0.20 & 1.00 & \\
\hline D Vitamin & 0.05 & - & $\overline{-}$ & 0.02 & -0.01 & 0.04 & $\begin{array}{c}- \\
0.29 \\
\end{array}$ & $\overline{-}-$ & - & $-\overline{26}$ & 0.07 & 0.09 & 0.06 & $\begin{array}{c}- \\
0.03\end{array}$ & $\begin{array}{c}- \\
0.14\end{array}$ & $-\overline{23}$ & - & $\begin{array}{c}- \\
0.10\end{array}$ & $\begin{array}{c}- \\
0.19\end{array}$ & - & $-\overline{0}$ & $\begin{array}{c}1.0 \\
0\end{array}$ \\
\hline
\end{tabular}


To demonstrate the correlation between the parameters studied in the two communities, we compared the values obtained in vectors for each parameter (Figure 1).

Figure 1. Principal component analysis with principal component variance between the analyzed parameters.

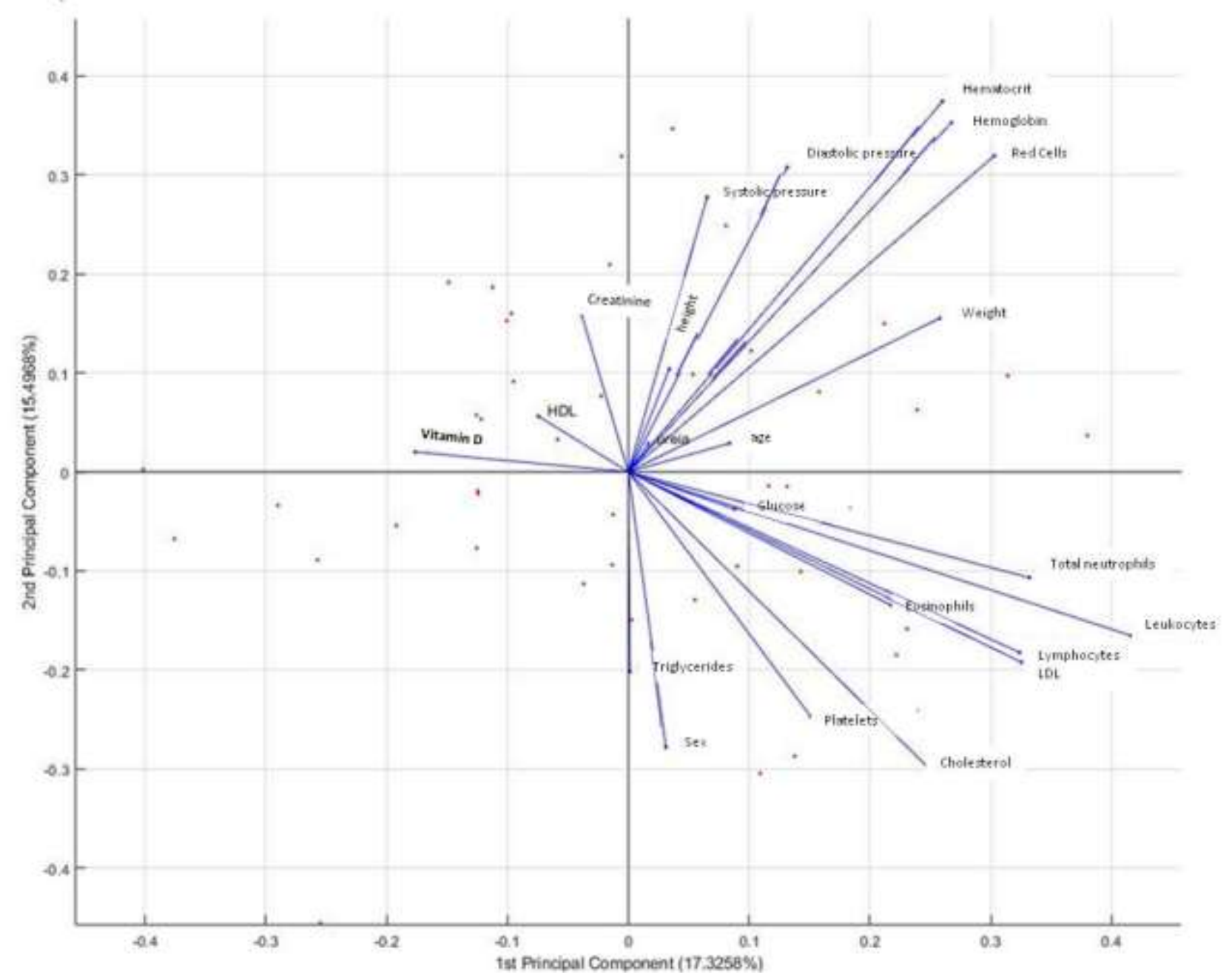

Source: Research data.

\section{Discussion}

In the results obtained with quilombola patients, four patients from each community were found, with values between 100 and $125 \mathrm{mg} / \mathrm{dL}$, characterizing altered fasting glycemia. One patient was obtained in the community of Silvânia-GO and two in Aparecida de Goiânia-GO with values greater than $126 \mathrm{mg} \backslash \mathrm{dL}$, with indicative of diabetes mellitus. In the quilombola community of Silvânia-GO, 18 presented total cholesterol values above the reference maximum and in the community of Aparecida de Goiânia-GO, eight patients presented results above the standardized maximum. When analyzing the results showed that triglycerides, HDL cholesterol and LDL cholesterol levels, were high in both communities (Table 1).

High values of lipid variables, excluding HDL-c, suggest higher susceptibility to pathological processes, such as atherosclerosis, stroke, infarcts, chronic wounds, amputations, renal failure and hypertension. The data from this study corroborate with those of the Faludi, et al. (2004), when defining the guidelines for dyslipidemia and prevention of atherosclerosis correlates diabetes with atherosclerosis, acute myocardial infarction with stroke. Defining those patients with diabetes and no risk factors or no evidence of subclinical atherosclerosis, should maintain LDL-C below 100mg / dL.

Patients with risk factors or subclinical atherosclerotic disease, should maintain LDL-c below 70mg/ dL. Patients with 
a history of AMI, stroke, coronary revascularization (carve or peripheral) and history of amputation; should maintain LDL-C below 50mg/ dL (Faludi, et al., 2017).

The NPC-1 protein promotes the passage of cholesterol through the wall of the intestine facilitating intestinal absorption of cholesterol. Hydroxymethylglutamyl CoA reductase is responsible for the intracellular synthesis of hepatic cholesterol and the one responsible for maintaining the blood LDL level. These enzymes suffer alterations in their function, structure, reduction of their expression in the membrane, leading to a disproportion in cholesterol levels and their fractions (LDL), this is due to monogenic or polygenic changes. The interaction between genetic factors and environmental factors (feeding, physical exercises) are responsible for the lipid profile of a population (Xavier, et al., 2013).

According to Faludi, et al. (2017), parameters for fasting glycemia are used for the laboratory diagnosis of diabetes mellitus. Fasting plasma glucose is considered to be eight hours as indicative of diabetes mellitus when it is $\geq 126 \mathrm{mg} / \mathrm{dL}$. In patients with results between 100 and $125 \mathrm{mg} / \mathrm{dL}$, "altered fasting glucose" is required, requiring an oral glucose tolerance test (OGTT) and 2 hours post-loading glycemia $\geq 200 \mathrm{mg} / \mathrm{dL}$ is indicative of diabetes mellitus and between $140 \mathrm{and} 200 \mathrm{mg} /$ $\mathrm{dL}$, of "impaired glucose tolerance". A second dosage is required when results are indicative of diabetes mellitus obtained at eight hour fasting and OGTT.

According to Lessa (2004), chronic kidney disease (CKD) is a worldwide public health problem and constitutes a risk factor for cardiovascular diseases. In these cases, serum creatinine is the most commonly used marker for screening for "renal dysfunction" in the population.

Fresnedo, et al. (2002), reports that under hemostasis conditions, the kidney consistently excretes all of the creatinine thus producing plasma creatinine inversely with glomerular filtration and in cases of increased serum creatinine, may reflect a loss of $50 \%$ of glomerular filtration. Therefore, it is very important to measure serum creatinine and to measure the glomerular filtration rate in order to carefully observe cases of renal insufficiency, together with pre-disposing factors and clinical signs and symptoms.

Regarding the urea parameter, in the community of Silvânia-GO, five patients presented values above the reference value, and at community of Aparecida de Goiânia-GO, there was only one patient with altered results for urea. In what refers to GFR, it is observed that 12 quilombolas in the community of Almeidas and 18 in the community of Aparecida, who presented between moderate to severe decrease of the renal filtration rate.

The altered values of urea and creatinine in the two studied populations may be suggestive of inadequate eating habits and decreased water intake. By correlating between glycemia values and altered lipid variables, they are associated with an impaired GFR. The Table 2 shows values below of $30 \mathrm{ng} / \mathrm{mL}$ in 12 patients living in Aparecida de Goiânia-GO; and in the Almeida Community in Silvia-GO, six patients with values below of $30 \mathrm{ng} / \mathrm{mL}$ were observed.

Vitamin D stimulates directly the expression of the insulin receptor in the cell, increasing the insulin response to the glucose stimulus and indirectly, through the concentration of intracellular calcium, which if it is decreased in the adipose and muscular tissue cells leads to a peripheral resistance to the action of (GLUT 4), demonstrating that Vitamin D has an action on the appearance of type 2 diabetes in individuals with decreased levels of vitamin D (2009).

On Sun and Zemel (2004) study, was observed that diets rich in calcium, occurs the suppression of circulating 1.25 dihydroxyvitamin D3, which decreases the intracellular calcium concentration of the adipocytes, stimulating lipogenesis and decreasing lipolysis (Matos et al., 2012). When the results of the hemogram were analyzed, it is observed that among the parameters of the red series, patients were found in both communities, with discrete decreased hemoglobin and hematocrit values, suggesting anemia (Table 3).

With regard to Aparecida de Goiânia-GO patients, changes in hematocrit and hemoglobin, were observed in a man and a woman, who presented values below the reference minimums. It was verified that the studied patients presented 
deficiency in relation to the cellular integrity (form, structure, concentration of hemoglobin) and red blood cells. Consequently, these patients may develop anemia, compromising both daily physical activity and cognitive ability.

The differential diagnosis of anemias is clinically important, because they have different causes, treatment and prognosis, and this reduces costs and improves the diagnosis of these anemias. In order to evaluate these variables, were used the hematological parameters (VCM, HCM and CHCM), hematocrit (HT) and hemoglobin (HB), and red cell numbers (Naoum \& Naoum, 2006).

Regarding blood leukogram results, data from Aparecida de Goiânia-GO showed four men and three women with neutrophils below the minimum reference values and one male patient with lymphocytes below the minimum reference value. In Silvia-GO, changes can be observed in relation to total neutrophils, where two men and one woman presented values below the minimum reference value.

The analysis of the leukogram, brings information of physiological responses of the organism to certain situations, they are classified in physiological, reactive and pathological. The physiological occurs when the increase of leukocytes in response to periods of stress, pregnancy and etc. C reactive protein occurs in response to bacterial infections, inflammation, tissue necrosis and metabolic diseases, when the physiological response occurs in relation to myeloproliferative diseases (myeloid leukemias, polycythemia Vera, myeloesclerosis) and lymphoproliferative diseases (lymphoid leukemias and some lymphomas are called leukocytosis pathological Naoum \& Naoum (2006).

When there is an increase in the number of leukocytes, it is called leukocytosis; in this case it is necessary to analyze the morphology of neutrophils (rods, metamielocytes, myelocytes and promyelocytes), toxic granulations, cytoplasmic vacuoles and abnormal inclusions. When young leukocytes are observed with nucleoli in a sample, it is suggestive of leukemias (Oliveira \& Caldeira, 2016).

According to the Mann Whitney test, total and LDL-C levels are high in both communities. The community of Almeidas (rural area), however, presented higher values. A study conducted by Oliveira and Caldeira (Vianna et al., 2011), in quilombola communities in the rural area of northern Minas Gerais, showed a sedentary lifestyle and inadequate food habits, smoking, excessive alcohol consumption and others.

Values of urea and Creatinine are higher in the community of Almeidas (Silvânia-GO) when compared to the community of cascades (Aparecida de Goiânia-GO), which raises the glomerular filtration rate, increasing the risks of developing insufficiency renal. The data of this study corroborate with those observed in the study by Oliveira and Caldeira (Steemburgo, et al., 2007). The results of total neutrophils are increased in the two communities, corroborating with the study by Vianna, et al. (2011) who observed that the inflammatory process occurs in the migration of neutrophils and other leukocytes to the lesion region.

A statistical evaluation of Spermanm was performed to compare a probable significance among the parameters studied in the communities of Almeidas (Silvânia-GO) and Cascatas (Aparecida de Goiânia-GO). Data are shown in Table 5. The correlations highlighted are statistically significant because they present $p<0.5$ where positive correlations are found, in which the two parameters increase together and the negative correlations, where one parameter grows and the other decreases.

According to the statistical test of Spermann, in this work, were found positive correlations between glycemia, pressure, triglycerides, red blood cells and neutrophils. Another positive correlation of sex with height, hematocrit, hemoglobin and lymphocytes was found and negative correlations were found for sex with hemoglobin and hematocrit. Positive correlations suggest that weight is closely related to factors such as glycemia, blood pressure, triglycerides, erythrocytes and neutrophils, because as the individual increases their weight, their body surface also increases and there is a greater storage and amount of tissue to be irrigated Obesity is one of the risk factors that induce the onset of metabolic syndrome (CRID, 2009).

Another positive correlation found between sex, hematocrit and hemoglobin was expected, considering that the 
hematocrit measures the amount of red blood cells in the blood volume and hemoglobin is contained in the red blood cell. The negative correlation of sex with hemoglobin and hematocrit is also justified in relation to the body surface being different in individuals of opposite sexes. The amount of red blood cells (hematocrit) and hemoglobin in red blood cells is different (Grotto, 2009).

The Figure 1 shows the analysis of the main components with variance of the main component among the analyzed parameters, showing the correlation between them. The Principal Components Analysis (PCA) was performed to verify if there is a grouping of results and if there is multiple correlation between them. After observation, main component 1 was observed to be $17.32 \%$ and main component 2 was $15.49 \%$. These values suggest that there is a weak correlation between the results.

The first correlation demonstrated is between HDL cholesterol and Vitamin D, we can observe in the Castro (2011) study, that during the production process of vitamin D, involving sun exposure, occurs primarily the endogenous synthesis in the lipid layer of 7-dehydrocholesterol skin (7-DHC), which undergoes the action of the converting enzyme dehydrocholesterol reductase (DHCR7), being converted into cholesterol which through sun exposure is transformed into the active form of vitamin D.

The third correlation demonstrated, occurs between leukocytes and LDL-c cholesterol. When there is atherosclerosis, initiated with an endothelial lesion, this pathology raises vascular permeability and accumulates lipoproteins, mainly LDL-c (low-density lipoprotein), which in turn accumulates in the endothelium and undergoes oxidation in its intimate layer by means of reactive oxygen species (ROS) released by endothelial cells and macrophages (Grotto, 2009).

\section{Conclusion}

In general, the laboratory results for the two communities showed increased levels of lipidogram, mainly HDL and LDL cholesterol and overweight body mass index, mainly in the Almeida population; anemia in both communities and the Glomerular Filtration Rate presented with a discrete to severe decrease. We observed that the health care offered by the Unified Health System (SHS) does not address all the health needs of these two quilombola populations studied. It is necessary to suggest a service protocol for this population, aiming at improving the public sector's assistance in solving or minimizing the health problems that afflict the quilombolas of the two communities studied in this research.

Quilombola communities are a population in which they deserve more studies and basic health care, public policies should be directed to this population. Additional studies must be carried out to indicate new bioindicators and health risk assessments can be carried out in this population.

\section{References}

ANS. Agência Nacional de Saúde Suplementar (Brasil). (2011). Manual técnico de promoção da saúde e prevenção de riscos e doenças na saúde suplementar (3a ed.), http://www.ans.gov.br/images/stories/Materiais_para_pesquisa/Materiais_por_assunto/manual_promoprev_web.pdf

Arruti, J. M. (2006). Mocambo: antropologia e história no processo de formação quilombola. Edusc. 370pp.

Campos M. O. C., \& Netob, J. F. R. (2008). Qualidade de vida: um instrumento para a promoção da saúde. Revista Baiana de Saúde Pública, 32 (2), 232-240.

Castro, L. C. G. D. (2011). O sistema endocrinológico vitamina D. Arquivos Brasileiros de Endocrinologia \& Metabologia, 55(8), 566-575.

CRID. (2019). Centro de Pesquisa em Doenças Inflamatórias. USP. http://crid.fmrp.usp.br/

Dusse, L. M. S., Rios, D. R. A., Sousa, L. P. N., Moraes, R. M. M. S., Domingueti, C. P., \& Gomes, K. B. (2016). Biomarcadores da função renal: do que dispomos atualmente. $R B A C, 49(1), 41-51$.

Failace R. (2015). Hemograma: manual de interpretação. (6th ed.), Artmed.

Faludi, A. A., Izar, M. C. D. O., Saraiva, J. F. K., Chacra, A. P. M., Bianco, H. T., Afiune Neto, A., \& Salgado Filho, W. (2017). Atualização da diretriz brasileira de dislipidemias e prevenção da aterosclerose-2017. Arquivos brasileiros de cardiologia, 109(2), 1-76. 
Fresnedo, G. F., CALABIA, E. R., Piñera, C., Herráez, I., Ruiz, J. C., Arias, M., \& De Francisco, A. L. M. (2002). Insuficiencia renal «oculta» por valoración de la función renal mediante la creatinina sérica. Nefrología, 22(2), 144-151.

Grotto, H. Z. (2009). O hemograma: importância para a interpretação da biópsia. Revista Brasileira de Hematologia e Hemoterapia, 31(3), $178-182$.

Gusman, C. R., Rodrigues, D. A., \& Villela, W. V. (2016). Trâmites éticos, ética e burocracia em uma experiência de pesquisa com população indígena. Saúde e Sociedade, 25, 930-942.

Koche, J. C. (2011). Fundamentos de metodologia científica. Vozes.

Leite, I. B. (1999). Quilombos e quilombolas: cidadania ou folclorização? Horizontes antropológicos, 5(10), 123-149.

Lessa, I. (2004). Doenças crônicas não-transmissíveis no Brasil: um desafio para a complexa tarefa da vigilância. Ciência \& Saúde Coletiva, 9, $931-943$.

Matos, J. F., Dusse, L. M. S. A., Gomes, K. B., Stubert, R. V. B., Ferreira, M. D. F. R., Moreira, R. C. N., ... \& Carvalho, M. D. G. (2012). O hemograma nas anemias microcíticas e hipocrômicas: aspectos diferenciais. Jornal Brasileiro de Patologia e Medicina Laboratorial, 48(4), 255-258.

Naoum, P. C., Naoum, F. A. (2006). Hematologia laboratorial - Leucócitos. Editora Academia.

Oliveira, S. K. M., \& Caldeira, A. P. (2016). Fatores de risco para doenças crônicas não transmissíveis em quilombolas do norte de Minas Gerais. Cadernos Saúde Coletiva, 24(4), 420-427.

Santos, R. C. D., \& Silva, M. S. (2014). Condições de vida e itinerários terapêuticos de quilombolas de Goiás. Saúde e Sociedade, 23, $1049-1063$.

SBD. Sociedade Brasileira de Diabetes. (2002). Consenso brasileiro sobre diabetes - diagnóstico e classificação do Diabetes Meliltus e tratamento do Diabetes Meliltus tipo 2. http://bvsms.saude.gov.br/bvs/publicacoes/consenso_bras_diabetes.pdf

Schuch, N. J., Garcia, V. C., \& Martini, L. A. (2009). Vitamina D e doenças endocrinometabólicas. Arquivos Brasileiros de Endocrinologia \& Metabologia, 53(5), 625-633.

SEDSG. Secretaria de Estado de Desenvolvimento Social de Goiás. (2018). Comunidades quilombolas em Goiás. https://www.social.go.gov.br/noticias/417seds-visita-mais-de-50-comunidades-quilombolas-e-cinco-reservas-ind\%C3\%ADgenas-para-levar-assist\%C3\%AAncia-social.html

Seidl, E. M. F., \& Zannon, C. M. L. D. C. (2004). Qualidade de vida e saúde: aspectos conceituais e metodológicos. Cadernos de saúde pública, 20, 580-588.

Silva, L. L. D., \& D'Amico, E. A. (2010). Estudo comparativo entre agregação plaquetária por turbidimetria e impedância elétrica em pacientes sob terapia antiplaquetária à base de ácido acetilsalicílico. Revista Brasileira de Hematologia e Hemoterapia, 32(6), 463-468.

Sodré, F. L., Costa, J. C. B., \& Lima, J. C. C. (2007). Avaliação da função e da lesão renal: um desafio laboratorial. Jornal Brasileiro de Patologia e Medicina Laboratorial, 43(5), 329-337.

Steemburgo, T., Dall'Alba, V., Gross, J. L., \& Azevedo, M. J. (2007). Fatores dietéticos e síndrome metabólica. Arquivos Brasileiros de Endocrinologia \& Metabologia, 51(9), 1425-1433.

Sun, X., \& Zemel, M. B. (2004). Calcium and dairy products inhibit weight and fat regain during ad libitum consumption following energy restriction in Ap2agouti transgenic mice. The Journal of nutrition, 134(11), 3054-3060.

Vianna, H. R., Soares, C. M. B. M., Tavares, M. S., Teixeira, M. M., \& Silva, A. C. S. (2011). Inflamação na doença renal crônica: papel de citocinas. Jornal brasileiro de nefrologia, 351-364.

Xavier, H. T., Izar, M. C., Faria Neto, J. R., Assad, M. H., Rocha, V. Z., Sposito, A. C., \& Ramires, J. A. F. (2013). V Diretriz brasileira de dislipidemias e prevenção da aterosclerose. Arquivos brasileiros de cardiologia, 101(4), 1-20. 